\title{
Exploration of Bauhinia variegata (Kachnar) and Cordia dichotoma (Lesora) for their Mineral Content
}

M. Awasthi ${ }^{1}$, R. Verma ${ }^{2}$

10.18805/ajdfr.D-4966

\begin{abstract}
Asian Journal Of Dairy and Food Research (2019)

\section{INTRODUCTION}

$B^{\prime}$ auhinia variegata (Kachnar) and Cordia dichotoma (Lesora) $B$ are wild vegetables and fruits grown and used as food in many tribal regions of India. B. variegata grows over North-East Indian sub mountainous tract as well as in lower dry regions of India, where its leaves and buds are used as vegetables (Kayang, 2007). C. dichotoma is a common fruit tree growing all over India used as food in rural areas (Saini et al., 2005). Compared to conventional cultivated species, wild vegetables and fruits are sometimes superior to the introduced cultivars. The present study was designed to explore the mineral content of B. variegata and C. dichotoma with their two stages of maturity.
\end{abstract}

Minerals play an important role in the metabolic regulations of the human body. Wild vegetables and fruits can be important and cheaper sources of minerals. In the present study, B. variegata and C. dichotoma, two wild foods with their two stages of maturity were analyzed for their mineral content. The study revealed that buds of $B$. variegata and immature fruits of $C$. dichotoma were high in calcium, magnesium, sodium, iron, and zinc than a mature stage. Flowers of $B$. variegata were rich in phosphorus, and mature fruits of $C$. dichotoma were good in phosphorus, potassium and copper content. The study concluded that both plants with two stages of maturity could be utilized as sources of minerals in combating mineral deficiencies.

Keywords: Buds, Calcium, Flame photometer, Immature fruits, Maturity stage.

\section{Materials and Methods}

The study was conducted during 2010-11 in the food analysis lab of College of Home Science, CSK HPKV Palampur. The raw material for the study was procured from the local villages of Palampur. The samples were dried and wet digested (Ranaganna, 2007). Sodium and potassium were analyzed using Flame Photometer. Calcium, iron, zinc, magnesium, and copper were analyzed by the atomic absorption spectrophotometer (Piper, 1996) while phosphorus was determined by vanadomolybdo phosphoric yellow color method (Jackson,1973).

\section{Results and Discussion}

The mineral content of $B$. variegata buds and flowers is presented in Table 1. Buds and flowers differed in their mineral contents. A remarkable difference was found in calcium, phosphorus, sodium, and magnesium contents of $B$. variegata buds and flowers. Calcium and magnesium contents were higher in buds (800.00 and $337.00 \mathrm{mg} / 100$ $\mathrm{g}$ respectively) as compared to flowers (134.00 and 190.00 $\mathrm{mg} / 100 \mathrm{~g}$ respectively). Whereas, phosphorus content was higher in B. variegata flowers ( $297.50 \mathrm{mg} / 100 \mathrm{~g}$ ) than buds
${ }^{1}$ Department of Nutrition and Dietetics, Faculty of Applied Sciences, Manav Rachna International Institute of Research and Studies Faridabad Haryana 121004

${ }^{2}$ CSK HP Agricultural University, Palampur, Himachal Pradesh

Corresponding Author: M. Awasthi, Department of Nutrition and Dietetics, Faculty of Applied Sciences, Manav Rachna International Institute of Research and Studies Faridabad Haryana 121004, Email: madhviawasthi84@gmail.com

How to cite this article: Awasthi, M. and Verma, R. (2019). Exploration of Bauhinia variegata (Kachnar) and Cordia dichotoma (Lesora) for their mineral content. Asian Journal Of Dairy and Food Research, 38(3): 265-266.

Source of support: Nil.

Conflict of interest: None

Submitted:14-06-2019 Accepted:09-10-2019 Published: 01-11-2019

(107.50 mg/100 g). The sodium, iron, copper, and zinc contents were also higher in $B$. variegata bud $(69.00,12.80,7.90$ and $6.60 \mathrm{mg} / 100 \mathrm{~g}$ respectively) than in B. variegata flower (55.20, $9.90,3.40$ and $5.10 \mathrm{mg} / 100 \mathrm{~g}$ respectively). This might be due to the higher ash content of $B$. variegata buds. But the content of potassium was same $(82.80 \mathrm{mg} / 100 \mathrm{~g})$ in both stages of maturity i.e., bud and flower. The mineral content of $B$. variegata flowers has also been reported in a study by Anonymous (1988). When flowers were analyzed for ash and minerals, it was reported that $100 \mathrm{~g}$ edible portion of $B$. variegata flower contained about $1.30 \mathrm{~g}$ ash. While calcium, phosphorus, and iron contents were reported as 70.10, 74.20 and $6.10 \mathrm{mg}$ per $100 \mathrm{~g}$ of edible portion respectively.

The content of minerals also varied in immature and mature $C$. dichotoma (Table 1). Immature C. dichotoma was higher in minerals than mature fruits. Calcium, phosphorus and magnesium contents in mature $C$. dichotoma were found to be 212,310 and $143 \mathrm{mg} / 100 \mathrm{~g}$, while in immature C. dichotoma these contents were slightly higher and were to the tune of 257,140 and $156 \mathrm{mg} / 100 \mathrm{~g}$ respectively. The 
Exploration of Bauhinia variegata (Kachnar) and Cordia dichotoma (Lesora) for their mineral content

Table 1: Mineral content of $B$ variegata and $C$ dichotoma (dry weight basis)

\begin{tabular}{lllll}
\hline $\begin{array}{l}\text { Minerals } \\
(\mathrm{mg} / 100 \mathrm{~g})\end{array}$ & \multicolumn{3}{l}{ Bauhinia variegata } & \multicolumn{2}{l}{ Cordia dichotoma } \\
\cline { 2 - 5 } & Buds & Flowers & Immature fruit & Mature fruit \\
\hline Calcium & 800.00 & 134.00 & 257.00 & 212.00 \\
Phosphorus & 107.50 & 297.50 & 140.00 & 310.00 \\
Magnesium & 337.00 & 190.00 & 156.00 & 143.00 \\
Sodium & 69.00 & 55.20 & 66.30 & 63.90 \\
Potassium & 82.80 & 82.80 & 130.28 & 150.54 \\
Iron & 12.80 & 9.90 & 5.90 & 5.80 \\
Copper & 7.90 & 3.40 & 2.00 & 2.50 \\
Zinc & 6.60 & 5.10 & 4.50 & 3.80 \\
\hline
\end{tabular}

maximum amount of sodium was recorded in immature fruits $(66.30 \mathrm{mg} / 100 \mathrm{~g})$. Potassium content was high in mature $C$. dichotoma $(150.54 \mathrm{mg} / 100 \mathrm{~g})$ while in immature fruits it was $130.28 \mathrm{mg} / 100 \mathrm{~g}$. Similarly, iron, copper, and zinc content were higher in immature $C$. dichotoma $(5.90,2.00$ and 4.50 $\mathrm{mg} / 100 \mathrm{~g}$ ). While the corresponding values for these minerals in mature C. dichotoma, were $5.80,2.50$ and $3.80 \mathrm{mg} / 100 \mathrm{~g}$, respectively.

Some variations were found while comparing the results of the present study with the data given by Kaushik and Dwivedi (2004). The values for calcium, phosphorus, zinc, iron and manganese contents analyzed by them were 55, 275, 2, 6 and $2 \mathrm{mg}$ per $100 \mathrm{~g}$ of $C$. dichotoma fruit respectively. Duhan et al. (1992) also reported similar values for phosphorus content on dry weight basis. Katiyar et al. (1990) and Valvi and Rathod (2011) have also reported mineral contents of C. dichotoma with some variations which may be due to differences in variety, stage of maturity, and agro-climatic conditions.

\section{Conclusion}

The present study revealed that $B$. variegata and C. dichotoma, with the two stages of maturity are rich in various macro and micro minerals. But They can be cheaper sources of minerals in the Indian community and can make an important contribution in combating micronutrient malnutrition as well as providing food security overcoming the mineral deficiencies of the people.

\section{References}

Kayang H (2007) Tribal knowledge of wild edible plants of Meghalaya, Northeast India. Indian Journal of Traditional Knowledge 6:177-181.

Saini RS, Kumar P, Verma JP, Singh S (2005) Preparation and preservation of Lesora (Cordia myxa Raxb.) pickle in water. Haryana Journal of Horticulture Science 34: 272-273.

Ranaganna S (2007) Handbook of Analysis and Quality control for fruits and vegetable products. $2^{\text {nd }}$ Edition, Tata Mc Graw. Hill Publishing Company, New Delhi.

Piper CS (1996) Method for the ashing of plant materials (Chapter-II). Hans Publishers, Nicol Road, Bombay.

Jackson ML (1973) Soil Chemical Analysis. Prentice Hall of India, Private Limited, New Delhi.

Anonymous (1988) Wealth of India. Publication and information Directorate of CSIR, New Delhi.

Kaushik RA, Dwivedi, NK (2004) Genetic diversity in Lesora. Indian Horticulture 49:1.

Duhan A., Chauhan, BM, Punia, D (1992) Nutritional value of some non-conventional plant foods of India. Plant Foods for Human Nutrition 42: 193-200.

Katiyar, SK, Kumar, N, Bhatia, AK, Sharma, K (1990) Composition of unconventional. Himalayan wild fruits. Journal of Food Science and Technology 27: 309-310.

Valvi, S.R., and Rathod, V.S. 2011. Mineral composition of some wild edible fruits from Kolhapur district. International Journal of Applied Biology and Pharmacological Technology 2:392-396 